
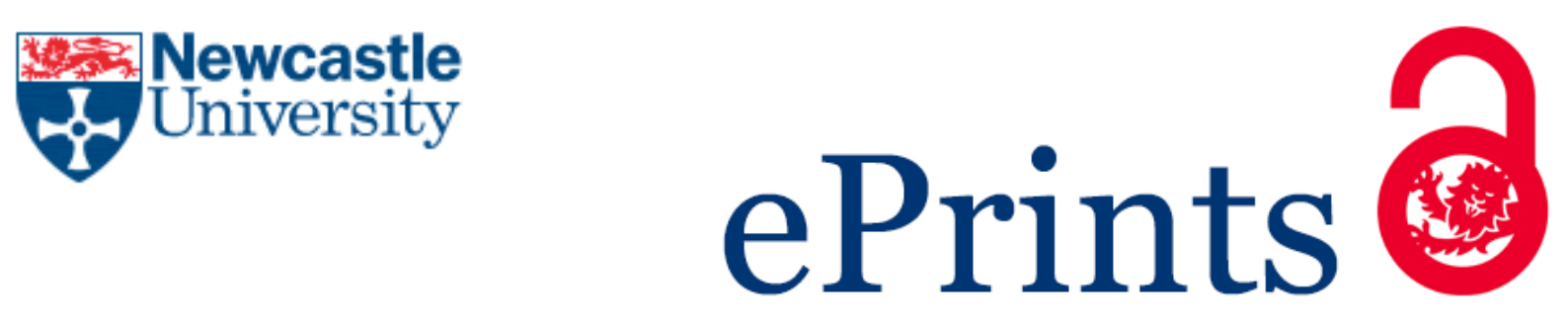

Degnen C, Tyler K.

Amongst the disciplines: anthropology, sociology, intersection, and

intersectionality.

The Sociological Review 2017, 65(1), 35-53.

\title{
Copyright:
}

Copyright @ 2017 The Authors. Reprinted by permission of SAGE Publications.

DOI link to article:

http://dx.doi.org/10.1177/0081176917693508

Date deposited:

$26 / 01 / 2017$ 


\section{Amongst the disciplines: anthropology, sociology, intersection, and intersectionality}

Cathrine Degnen and Katharine Tyler ${ }^{1}$

\section{Abstract}

The history of relations between anthropology and sociology in the UK might at best be described as 'studied indifference'. And yet, they have shared disciplinary interests in many respects, including the concepts of belonging and identity. This article resists disciplinary boundaries and 'thinks together' sociological interpretations of intersectionality and anthropological notions of intersection. We argue that whilst intersectionality offers a frame to think about the co-constitution of ethnic, racial, class, sexual and gendered identities and the production of social inequalities, anthropological approaches to intersection draw on a cultural form and social logic encountered during ethnographic fieldwork that emphasises ideas about interrelatedness, belonging, place, temporality, connection and disconnection. In juxtaposing these two

\footnotetext{
${ }^{1}$ This co-authored paper draws equally upon the experience and ideas of both Degnen and Tyler who have each also contributed equally to its writing.
} 
approaches, we seek firmer traction to better articulate the shape and scope of the ways in which scholars in both fields might develop new ways of explaining the lives and the concerns of the people we work with.

Keywords: intersectionality, intersection, sociology, anthropology, identity, belonging, ethnography and Britain

\section{Introduction}

What does it mean to practice an anthropology of Britain? What does it mean to do this in conversation with sociology? And why should either question matter to anthropologists not working in Britain and to sociologists not particularly interested in anthropology? In this article, we seek to explore answers to all three questions by selectively juxtaposing the two disciplines perspectives on identity, and then put those perspectives to work on our own ethnographic material. We say 'selectively' as we recognise that both anthropologists and sociologists have taken any number of different approaches to identity over the past twenty years, and our article focuses primarily on only one strand from each discipline. So whilst in this regard no doubt our approach can always only 
be partial, we are also confident in what our approach makes possible: generating insight across the disciplinary divide on topics of shared interest.

We recognise that this may strike some fellow social anthropologists as a peculiar strategy, given a history of relations between anthropology and sociology in the UK which might at best be described as 'studied indifference'. Indeed, it is this paradox of two disciplines, so closely related and yet so persistently estranged from each other, that has vitalised this article (see also our Introduction to this volume). We consider anthropology and sociology to be sister disciplines, but ones that most often keep each other at arm's length. We recognise that a sense of belonging to either 'anthropology' or 'sociology' is not a simple equation, and that academic identities, like all identities, are partial, fluid, hybrid, contextual, strategic and contradictory. But we also know that a sense of belonging and the practices and ideologies put to work to shore up these categories have tangible effects in the world. When identities can be said to be in tension, as we sense they are between anthropology and sociology in Britain today (no matter how porous the boundaries between them may be), that tension in turn produces something interesting to consider. 
Furthermore, identity and belonging are also shared theoretical points of interest for both anthropologists of Britain (e.g. Cohen, Edwards, Frankenberg, Macdonald, Okely, Strathern) and British sociologists (e.g. Alexander, Bottero, Giddens, Gilroy, Hall, Jenkins, Lawler, Savage, Skeggs). In this article, we seek to articulate the ways in which the anthropology of Britain can creatively and productively be put into conversation with sociology to usefully explain the lives and the concerns of the people we come to know and work with. To achieve this, we juxtapose the sociological concept of intersectionality with some of the ways in which the anthropology of Britain has deployed the notion of intersection. We have chosen to focus on these two approaches to identity that have both attracted a great deal of recent thinking and writing in their home disciplines. We argue that these terms placed side by side help to think through the sociological and the anthropological in approaches to identity, belonging, difference and inequality. We will argue that whilst intersectionality offers a frame to think about the co-constitution of ethnic, racial, class, sexual and gendered identities and the production of social inequalities, anthropological approaches to the "power of ... intersection" (Edwards \& Strathern, 2000, p. 150) draw on a cultural form and social logic encountered during ethnographic fieldwork that emphasises ideas about interrelatedness, belonging, place, temporality, connection and disconnection. In this regard, sociological 
approaches to intersectionality offer a theoretical approach to inequality and oppression. By contrast an anthropological approach to intersection is intended to account theoretically for popular ideas and everyday experiences of connection and belonging as heard, seen and learnt via fieldwork.

Our argument is that the conjoining of these approaches opens up a productive space for the analysis of multiple identity formations and structures of inequality that neither approach can quite capture and explain without the help of the other. Moreover, we contend that reflecting on the contrasts between these two approaches can help us move away from essentialist and divided notions of the disciplinary identities themselves of anthropology and sociology. In this paper, we put these proposals experimentally to work on two samples of ethnographic material from our own fieldsites. We do this in order to render more explicit the relationship between these disciplinary frames and to illustrate and explore what thinking "amongst the disciplines" (Donaldson, Ward, \& Bradley, 2010) might permit and reveal. In order to elaborate upon these relations, we turn first to sociological commentary on the concept of intersectionality. 


\section{Sociological and anthropological theoretical framings: intersectionality and intersection}

Sociology: intersectionality

Intersectionality is both a theoretical and a methodological approach to the study of inequalities (Choo \& Ferree, 2010, p. 130). An intersectional paradigm puts into view "the relationships among multiple dimensions and modalities of social relations and subject formations" (McCall, 2005, p. 1771) in order to better understand how it is that multiple forms of oppression come to be lived and experienced. That is to say, oppression and subordination are lodged in various subject positions and social divisions such as gender, sexuality, race, age and class. An intersectional paradigm seeks to illuminate how "the intersecting oppressions are mutually constituted by each other. There is no meaning to the notion 'black', for instance, which is not gendered and classed, no meaning for the notion of 'woman' which is not ethnicized and classed" (Yuval-Davis, 2007:565; see also Davis, 2008, p. 71).

This perspective is often described as a non-additive approach to studying social inequality including the reproduction, maintenance and control of racism, 
sexism and exclusion on class grounds. This is because one form of subordination is not simply layered or added onto another, but instead that there is a "transformative interactivity" of these forms of subordination (Choo \& Ferree, 2010, p. 131). A metaphor for this could be the processes of baking, for instance, whereby the constitutive elements are changed in the presence of each other and via the conditions under which they meet in the oven. And yet this process of intersection is not in any way reductive. For example, McClintock (1995) in her highly influential study of gender, race and sexuality under colonial conditions argues that these domains are "not reducible to each other, or identical with each other, instead, they exist in intimate, reciprocal and contradictory relations with each other" $(1995$, p. 5). Thus, the notion of intersectionality invites social scientists to consider the transformative ways in which forms of difference come together and are experienced, taking into consideration individual experiences and how power is reproduced via social practices, institutional formations and ideologies (Davis, 2008, p. 68). Moreover, the focus is not simply on relations between forms of difference but also how the categories of race, sexuality and gender, labour and class historically come into being in the first place (McClintock, 1995, p. 16). 
An even cursory literature review quickly demonstrates the range and scope of interest that intersectionality has attracted, certainly meriting its labelling as a "buzzword" in contemporary social science (Davis, 2008). The origins of the concept reside in the work of Crenshaw $(1989 ; 1991)$ and have subsequently been taken up by many feminist sociologists (Davis, 2008; McCall, 2005; Walby, Armstrong, \& Strid, 2012; Yuval-Davis, 2007). Crenshaw first used the term in a now well-known law review article dealing with how race and gender intersect to restrict American black women's employment opportunities (Choo \& Ferree, 2010; Walby et al., 2012; Yuval-Davis, 2007), and to render black women invisible in American employment law.

Her insights paralleled black feminist critiques of white feminists who "write their herstory and call it the story of women but ignore our lives and their relation to us" (Carby, 1982, as cited in McClintock, 1995, p. 7). Black feminists have argued that the "historical amnesia" of black women in white women's writing ignores the ways in which white women have benefited from black women's oppression (Amos and Parmar, 1984, as cited in McClintock, 1995, p. 7). Thus, taking an intersectional standpoint has enabled scholars to write in the experiences and voices of those who have been forgotten, ignored and excluded. One consequence of this is that the often unnoticed and unmarked 
power of hegemonic groups and institutions is made visible and thus can be confronted and curtailed (Anthias, 2013; Choo \& Ferree, 2010; Carbado, 2013).

Within sociology race, class and gender have been the dominant forms of oppression that intersectionality has most often sought to examine in relation to each other (Choo \& Ferree, 2010). However, this has expanded over time to include a wider range of inequalities such as "ethnicity, disability, age, sexual orientation and religion" (Walby et al., 2012, pp. 224-225). Moreover, a number of methodological approaches to intersectional analysis have been developed by sociologists (Choo \& Ferree, 2010, p. 130; McCall, 2005). For example, Brah (2000) in her analysis of the interconnections between race, class, gender and sexual identities and inequalities eloquently sets out a method for interrogation of these relations and inequalities that must take account of: a) the contemporary and historical contingent nature of relationships; b) the macro and context-specific manifestations of differentiation and c) the wider economic, political and ideological processes involved in sustaining particular social divisions within groups.

Intersectionality has garnered so much attention (including within sociology) that it is now lauded as "the most important theoretical contribution that women's 
studies, in conjunction with related fields, has made thus far" (McCall, 2005, p. 1771). This is partly for the way in which intersectionality came together with postmodern deconstructionist and poststructuralist research agendas to breakup fixed and essentialist notions of identity (Davis, 2008, p. 71), but also for the ways in which it "encourages complexity, stimulates creativity, and avoids premature closure" (Davis, 2008, p. 79). It is precisely a rejection of closure, a critical engagement with inequality including racism, sexism, homophobia and class inequality and the desire to take-nothing-for-granted which anthropology also claims. Indeed, this desire is one which some intersectionalist theorists have also asserted for anthropology (McCall, 2005, p. 1782), a point to which we shall return to below.

Nonetheless, given the reach of intersectionality as a "buzzword" across the social sciences, it is striking how intersectionality has not by and large attracted much interest amongst anthropologists of Britain. We argue that this is because anthropologists have other disciplinary frames that they tend to rely on. We turn our attention now to one of these, namely, intersection. 
Anthropology: intersection

Whilst similar terms, the distinction between 'intersectionality' and 'intersection' is more than a simple difference in semantics. By contrast to intersectionality, intersection is not a firmly agreed upon term within the anthropological literature. However, we use the term here to describe a conceptual approach to belonging that we have identified within anthropological literature generally and the anthropology of Britain in particular. Intersection in the anthropological literature is both an analytic frame and an ethnographic reality. It refers to forms of cultural meaning that underpin social relations and everyday life. These forms of cultural meaning emphasise how things are predicated on "partial connections", on a simultaneous holding together and keeping apart which in turn reproduces parameters of belonging, attachment and identity (Strathern, 1994; Edwards, 2000). It is these intersecting and overlapping forms of sociality out of which daily life is shaped that anthropologists often seek to convey in their writing. Intersection thus occurs in the banality of the moments and practices of everyday life. It becomes a part of the processes running through social life that articulate formations of belonging and identity. However, whilst perceiving intersection is integral to anthropological theory and method more 
generally, it is the ways in which anthropologists of Britain have understood and articulated this approach that interests us here.

A recurring theme in the anthropology of Britain is how seemingly very separate domains of material and social worlds are brought together to assert belonging and connection. This "cultural work" (Green, 2002, p. 198) characterises the diverse ways in which individuals, families, friends, neighbourhoods and communities use the "power of imagining... intersection" (Edwards \& Strathern, 2000, p. 150) to form relationships, attachment and belonging. These connections are forged through the "associations of disparate elements" (Edwards \& Strathern, 2000, p. 150) and "interrelated tracks and circles of life" (Rapport, 2002, p. 315). Elaborating on this cultural form, Edwards and Strathern propose that a sense of belonging, identity and relatedness involves a constant "interweaving", "interdigitation" and construction of "diverse kinds of linkages" (2000, p. 158). Intersection here thus evokes what is socially woven together in order to achieve belonging. What precisely is woven together includes a surprising range of subjects, material objects, places, landmarks and knowledge including accent, homes, shops, family names, farms, paths, pubs and social memories (Edwards, 1998; 2000; Degnen, 2005, 2013; Tyler, 2005). 
Whilst the creative potentiality inherent in the intersection of multiple aspects of sociality might appear "intrinsically desirable" (Edwards \& Strathern, 2000,p. 152), these relationships also define who does not belong and serve to exclude. In this sense, by defining "our own" a boundary is constructed against "outsiders", "strangers" and "offcomers", but also at the more intimate level within, say, families, whereby some members can come to be excluded in a multiplicity of ways (Edwards \& Strathern, 2000, p. 153; Rapport, 1993; Cohen, 1982; Werbner, 2002). Additionally, whilst people forge belonging by "enlisting persons and 'things', concrete and abstract (factories, houses, dialect and kinfolk)", they also "screen out such connections when they enlist a different, albeit partially overlapping, set of persons and 'things'. Making connections always entails breaking connections" and "distinction... is... mobilised as a conceptual means of differentiation" (Edwards, 1998, p. 155). In short, intersection includes analytical attention to how the various components of social realities are held together and/or kept apart - and what that in turn accomplishes - socially encompassing a wide range of animate and inanimate elements.

The specificity and local constitution of these processes of intersection out of which daily life is formed have been explored via fieldwork in a wide range of British social milieus over many decades. First evident in Frankenberg's (1957) 
ground-breaking study of hierarchy in a village on the Welsh/ English border, the theme reoccurs in seminal pieces in the anthropology of Britain including: Strathern's (1981) study of kinship in the Essex village of Elmdon; Cohen's (1987) famous work in the Shetland Islands; and Edwards' (2000) influential study of a post-industrial former mill town in the north of England, amongst others. Crucial to this work has been analysis of the locally specific ways in which villagers and townspeople "construct chains of association that enlarge their own sense of belonging to families by belonging to place" and community (Edwards \& Strathern, 2000, p. 151; see also Koch, this volume).

So, for example, Rapport (2002, p. 304) eloquently describes the intersection of various forms of "reciprocal physicality" that unite villagers, spanning and incorporating "managing a farm, bringing up a family, having sex, inside marriage and out ... playing darts and dominoes", "drinking", "dancing" and "sharing gossip". In contrast, he found that "outsiders" to Wanet might "know of events and overhear gossip", but they "do not partake of the doing" (Rapport, 2002, p. 314). Thus for example, the Anglican vicar and his church remained "physically apart" from Wanet's living community. Rapport explains "for as life in Wanet is represented by interrelated spheres of physical engagement, so church and vicar may be represented by an isolation, a separating-out: the 
ethereal as distinct from the workaday, the innocent separated from the pragmatic, purity isolated from physicality" (2002, p. 316). In this way, the vicar and the Church stood outside the physical sociality out of which daily life was formed for villagers in Wanet and through which they were connected.

It is in these ways that anthropological studies of Britain illuminate a particular social form and logic centred upon the intersection of diverse domains of sociality to support and maintain ideas and practices of belonging, relatedness, identity, inclusion and exclusion. This worldview conveys a "field of operations" of connection and disconnection that is "repeated over and again on a daily and ordinary basis" (Edwards \& Strathern, 2000, p. 150). Consequently, this "common discourse" captures the "expression of a great and changing diversity of meanings, moods and motivations: a means to realize the individual worldviews of ... [English] farmers, [Welsh] villagers", Scottish fishermen, northern townspeople and anthropologists alike (Rapport, 2002, p. 318). 


\section{Bridging intersection and intersectionality}

We return now to the key concern of this paper: what becomes possible when we juxtapose intersectionality and intersection, when we think with them together? Our first contention is that these concepts share similar epistemic objectives: both perspectives are concerned with understanding the formation of identity, difference, differentiation and inequality. Motivating both approaches is a desire to examine and unravel the taken-for-granted-ness of social worlds in order to better understand forms of sociality. Moreover, these concepts have also permitted anthropologists and sociologists to examine the ways in which people negotiate bigger global socio-economic and political forces and historical legacies, including for example relations of colonialism, capitalism and postindustrialism, by asking "what these phenomena actually signify to everyone caught up in the processes that occur under their name" (Comaroff \& Comaroff, 2012, p. xxxvii). Indeed, both approaches share a desire to make sense of the rhythms of the everyday (a point that Lawler highlights in her preface to the volume). Both approaches are also attentive to the ways in which social life is "socially constructed and represented in various discourses" (Brah, 2000,p. 434). In this sense, we recognise shared disciplinary interests within Davis' suggestion that the sociological concept of intersectionality triggers "a process 
of discovery, alerting us to the fact that the world around us is always more complicated and contradictory than we ever could have anticipated. It compels us to grapple with this complexity in our scholarship" (Davis, 2008, p. 69). The same can be said for anthropological approaches to intersection. In short, both concepts are motivated to engage in a deep way with the social complexity of everyday life as it is lived and experienced.

Yet, we contend that there is a significant discrepancy between each discipline's approach to the analysis of identity. On the one hand, an anthropological approach to intersection is located within and emerges from analysis of cultural forms of knowledge, shared discourses and representations about the world. For an anthropology of Britain exploring intersection, the theory has in effect come from the ethnography of local British people, places, relationships, sites and milieus. Thus, the anthropological focus on intersection has been generated by ethnographic engagement with aspects of British social life that insist on intersection and, in turn, demand an accounting of intersection from the ethnographer. The anthropology of intersection has not been grounded first in theory, but rather is a framework that has emerged and advanced via immersion in local, placed ethnographic practice, one based on listening and engaging with people and their often intense forms of localism. 
On the other hand, sociological theorising of intersectionality emerged (initially) from theoretical reflections on black women's experiences of oppression and inequality in the face of white male western patriarchy. The subsequent outpouring of rich sociological insights on identity, difference, inequality and diversity that has come from these observations has rendered intersectionality a theory and method that transverses and transcends specific cultural forms. It can be applied to a range of contemporary context-specific settings, macro and global institutions and historical milieus. It is not anchored to localised cultural forms of meaning - rather, local detail takes meaning in relation to analysis of the various categories of social division, oppression and subordination.

It seems to us, then, that while intersectionality is a theoretical approach to inequality and oppression, intersection is intended to describe everyday discourses, relationships and experiences of connection and belonging - as heard, seen, learned and appreciated through ethnography. Following on from this, where intersectionality focuses on the key mechanisms of inequality and injustice, the anthropological preference is less confined to inequality per se and ranges over various registers of human experience. Consequently, intersection has a more expansive reference to everyday points of connection out of which 
sociality, belonging, meaning and memory are constructed. Or again, intersectionality highlights what is in a sense life-negating (i.e. what activists seek to resist); intersection is more inclined to celebrate what is life-affirming. The sociological notion of intersectionality does not really get much purchase on anything that is not directly political; while the anthropological approach to intersection risks a depoliticised portrayal of people's lives. Thus we contend that while the two terms do not exactly parallel one another, they can readily complement each other ${ }^{2}$.

From this perspective, an anthropological approach to intersection can powerfully expand sociological theorising on the intersectionality of race, ethnicity, class, gender, sexuality. Moreover anthropologists studying aspects of British social life can draw on lessons from feminist sociologists of intersectionality in their capacity to keep in analytical view the always already raced, classed and gendered constitution of identities and production of inequalities. In this sense, we want to extend Choo \& Ferree's (2010) critique of qualitative studies within sociology on aspects of American social life to anthropological ethnographies of Britain. That is to say, more often than not

\footnotetext{
${ }^{2}$ Our thanks to Peter Phillimore for his valuable insights here that helped us make our point more clearly.
} 
anthropological studies of Britain do not show how "gender, race, and class can be working together to draw boundaries and reproduce complex inequalities in the system as a whole" (2010, p. 137) because, arguably, they remain grounded in the micro level of localism. From this point of view, one of the creative methodological and theoretical strengths of the anthropology of Britain - that is its focus on the manifestation of intense forms of localism - can also become perhaps a limitation, with a similar charge able to be levied against sociology - but in the opposite direction.

In the remaining sections of this article, we turn this challenge back onto ourselves. We weave together anthropological approaches to intersection with the sociological concept of intersectionality in an attempt to explain the everyday reproduction of identities and inequalities that we experienced in our respective fieldworks within former coalmining areas of England. Our analysis of our ethnographic material provides us with a platform from which to elaborate upon our understanding of the potentialities inherent in a more explicitly rendered relationship between the sociology of intersectionality and the anthropological study of Britain. 


\section{At the coal face: living intersection(ality)}

Quite by chance, we both conducted fieldwork in former British coal mining areas as doctoral students - Tyler in Leicestershire, a region situated in the middle of England and Degnen in South Yorkshire, a county located in the north of England. There are significant differences between these two locations in terms of their industrial coal-mining histories and post-industrial afterlives, but so too are there a number of social and cultural similarities. Up until the 1980 s coalmining in Britain was a major industry that maintained and reproduced a whole way of life for generations of coalminers and their families. From 1984 to the early 1990 s the Conservative government systematically closed coalmines across Britain, a policy that echoed processes of deindustrialisation taking place at that time across the Western world. In Britain, this had the effect of dramatically transforming the lives of people dependent on the coalmining industry for work, thus also disrupting the socio-economic constitution and identities of mining communities, villages and towns.

The research questions that motivated our doctoral projects took meaning in the face of these processes of deindustrialisation. However, the focuses of our questions were very different: Tyler examined everyday ideas of national 
belonging and whiteness in the context of deindustrialisation, whilst Degnen explored ageing, social memory and social transformation. Also different were the intellectual traditions we had trained in -- Tyler in British social anthropology and Degnen in medical and cultural anthropology in North America.

Additionally, we had different ways of working in our fieldsites. Tyler spent six months living in the Leicestershire coal-fields, a period of fieldwork that came to form part of over two years of multi-sited residential fieldwork in the region spanning her doctoral and postdoctoral research (see Tyler, 2012).

Significantly, Leicestershire was also a place where Tyler had spent many years growing up. In contrast to Tyler, Degnen arrived in the UK from North America, having never lived there before, to conduct her fieldwork (see Degnen, 2012). She then spent five years living in her fieldsite, making the village her home and subsequently carrying out a second period of research there as a postdoc. As such, both of us developed important personal connections to where we were working. That is to say, our biographies and identities are entangled in deeply personal ways with our research sites and participants.

It is these shared and yet divergent biographical and research experiences that we draw on in this next section of our paper. In an earlier incarnation of this 
article, we collaborated in an attempt to think through what an anthropology of Britain might mean. To do this, we devised an experimental ethnographic writing exercise. We challenged each other to think about an aspect of our ethnographic research that we had not yet written about but which we felt to be worthy of closer inspection; to go away separately to produce accounts of them; and then to bring these two pieces of ethnographic writing together into conversation.

In so doing, we did not set out to highlight themes that we thought were paradigmatic of an anthropology of Britain or sociology, nor did we have ideas of identity, intersection and intersectionality in mind. That came later. Indeed we did not discuss in advance in any detail the material we were thinking about using. Rather, we wanted to see, experimentally, where we might get to by juxtaposing our ethnographic material and seeing what happened. It is from the ethnographic material generated via this experiment that this paper's theoretical focus on intersection and intersectionality has evolved and developed since this article's first incarnation.

Degnen chose to write about a locally important building from her fieldsite in Dodworth, South Yorkshire, a former coalmining village, and Tyler chose a 
vignette drawn from the early days of her fieldwork in Coalville, a former coalmining town in north-west Leicestershire. We recognise that, given the overlapping social, cultural, economic and historical contexts of our research sites, there is to a certain extent an inevitable comparability that is built into our material. But it is not this that interests us most. Instead, the analytical challenge for the purposes of this article has been to think about the data both in terms of intersection and intersectionality. We present Degnen's example first, followed by Tyler's, and then analyse the data in tandem through the lens of intersection(ality).

\section{Wentworth Castle revisited}

No more than half a mile from Dodworth, a village that for over 150 years until the mid-1990s was heavily dependent on the region's coal and steel industries, there is a substantial stately home. Called Wentworth Castle, it sits high on the hillside in the midst of extensive formal gardens. Now the home of the Northern College, Wentworth Castle was owned in the 18th century by the Earls of Strafford and in the late 19th century by the Vernon-Wentworth family. 
In many ways, the presence of the Castle and what it symbolises in terms of substantial multi-generational wealth, power and influence is incongruous with the socio-economic (largely) working class industrial and agricultural histories of Dodworth. But the scale of oral histories connected to the Castle that Degnen was told, and the more recent restoration projects transforming it into a tourist attraction and commercial wedding venue, are revealing of nested and intersecting layers of belonging and experience, both locally and more widely.

During Degnen's time in Dodworth, the main building itself and surrounding gardens were decaying. Saplings boldly grew from roof lines; ornate outbuildings made of sandstone were literally melting away with erosion; the vast Victorian wrought-iron greenhouse was in complete ruin. However, as Degnen eventually came to understand, Wentworth Castle is more than a building and garden. It is a fulcrum for multiple generations' personal histories, shared experiences and diverse senses of belonging to each other and the area. It is an index of substantial shifts in broader socio-economic and political epochs of British history. This is due to the aristocratic spheres of power that the $18^{\text {th }}$ century owners were enmeshed in - Thomas Wentworth's great uncle was Lord Deputy of Ireland and later executed by Charles I; Wentworth himself was Knight of the Garter, ambassador to Berlin and then to the Hague, involved 
in the negotiations over the Treaty of Utrecht as well as serving as First Lord of the Admiralty - but also how eventually it came to be owned by the local council post World War Two, paralleling the wider demise of the English country house.

It is the Vernon-Wentworths who eventually inherited the Castle that are the branch of the family best remembered by the people Degnen worked with, and in particular, "Captain Wentworth", the last generation of the family to own and reside in Wentworth Castle. He was both a local character and employer in the era before and immediately after the Second World War as the large property required housekeepers, cooks, cleaners, laundry maids, gamekeepers and gardeners to maintain it.

Dodworth, and the other surrounding villages, provided a ready source of labour for the Castle. Traces of these connections emerged repeatedly over the course of Degnen's fieldwork, from the postcard in Edna's treasure box she showed Degnen, sent by her mother to her grandmother when her mother was away "in service" with the Vernon-Wentworths at their summer house near Kinloch Rannock in Scotland in the 1890s, to Margaret's recollections to Degnen of how the Captain dressed so badly that he "looked just like a tramp!", to the black and white photographs of Dennis in the Victorian greenhouse before it fell into 
disrepair when he worked as a gardener at the Castle. Stories of the Castle and the family connections to it over upwards of three generations abounded, as well as personal memories and experiences of people in their 50 s, 60 s, 70 s and 80s that Degnen came to know in Dodworth and the neighbouring villages.

Leisure figured as a way in which people came to 'know' the Castle, too. This included frequent dances held in the Castle during World War Two, which for some was also the first time they had come into regular contact with American service men stationed nearby, and a number of whom were African American. This meeting of and socialising with African Americans was still noteworthy decades later when being recounted to Degnen by research participants - "we had never seen people like them before" - and commented on by them. Leisure at the Castle also included access to the 38 acres of gardens and parkland which many local people had a deep attachment to and had enjoyed access to varying degrees over the decades. The rhododendron collections in these grounds were of particular significance in people's accounts of the Castle, especially at Whitsuntide when they were open annually to the public for a few days. 
After ownership of the Castle transferred to Barnsley Council in 1951, it seems that access to the grounds became less controlled. Members of the public could, discreetly, walk through the grounds at their leisure. As time passed and the gardens became more and more overgrown, the ability to do this became enhanced, as did the atmosphere of the gardens which, according to many, benefited from a quasi-return to nature. Many wandering paths were covered by a high tree canopy and much undergrowth which offered a gloaming sense of tranquil mystery, where one could turn a corner and be transported by the vista, or by hearing the resident owl high in the canopy above.

However, in 2004-5, an intensive and controversial regeneration project of the gardens and buildings was beginning as part of a heritage and tourism project. The ethereal-feel to the gardens was destroyed in the opinion of many, with large sections of the overgrown areas entirely removed. This was done partly in order to restore a highly sculpted garden from the 1700 s, called the "Union Jack Gardens" planned by the first Earl in 1714 to mark the Act of Union between England and Scotland. Holly, yew and laurel hedges are used to create walkways that are in the shape of the Union Jack when viewed from the air. The extent and nature of this restoration project disrupted the relationship of some to the gardens, erasing as it did an atmospheric space, but also by ushering in a 
new era of restricted access to the property, a property that many local people felt belonged to them.

\section{A night-out in Coalville}

Tyler had been living in Coalville for about two weeks when Mike invited her to go out with him one evening. Mike was 26 years old. He had been unemployed for two years after completing an undergraduate degree and was living at home with his parents in the town. His father was a worker at the town's brick yard and his mother a dinner lady at a local school.

Tyler had met Mike in the Labour Party offices in the town centre and had explained to him that she was interested in the changing socio-economic composition of Coalville in the post-mining era, as well as the relationships between whites and Asians in the town. Mike's upbringing in the area and his engagement in local politics made him very interested in Coalville as a place and the people who lived there. Consequently, Mike was also interested in Tyler's research. 
Mike invited Tyler out on this particular evening to watch with him an England vs Moldova football match on the big television screens in the pubs in Coalville. Knowing that Tyler was interested in ideas of Englishness in Coalville, Mike thought Tyler might like to watch the game. He also said that after the football match he would take her on a drive around the town.

At the time, Tyler was lodging with two women who were sisters. They lived in a house in a former mining village on the outskirts of Coalville. When Tyler told the women that she was off out on a drive around the town, one of the sisters explained that she was not being "snobby or anything like that" but she would not go out in Coalville. She much preferred a night out in the village that they were living.

Mike met Tyler in his mum's car and they drove to Coalville's town centre. Their first stop was 'The Coalminer's' pub on the outskirts of the town. Tyler ordered a tomato juice at the bar. Mike commented that this was an unusual drink to order and jokingly suggested that the barmaid would have to "brush the dust off" the top of the bottle. This pub was not very busy and so they moved onto another pub named after the town's former colliery, the main shaft of which is still visible in the town centre. 
This pub was packed with white men of different ages. The men were facing towards the big screen showing the football match. The Union Jack flag was draped underneath the television screen. The pub was minimally furnished, and the walls were decorated with glass cabinets that displayed mining equipment from differing eras. While Mike ordered the drinks at the bar, Tyler stood in a corner of the pub waiting for him. Some men called over: "Sit down love, you look awkward". Tyler could tell from their accents that the men were from the South of England. They told her that they were lorry drivers from London who had parked in Coalville for the night. They explained how she had just missed a moving tribute before the start of the football game on the television to Princess Diana, who had died in a car crash ten days earlier. Tyler and the men also discussed the English football fans waving of the St George's flag with the name DIANA written in black capitals around the red cross of St George, as well as the black arm bands symbolising morning worn by the English team's footballers.

England won the game. Mike explained to Tyler that it was what was expected because nobody knew where Moldova was. After the game Mike and Tyler set off for a drive around Coalville and its surrounding areas. 
First, they drove around the various housing estates surrounding the town centre. While he drove Mike pointed out the council house (public housing) where his grandmother had lived. He explained how she was very proud of that house because it was an improvement on the condemned miners' terraces where she and her family had previously lived. Mike later told Tyler that he could not understand why his uncles were "heartbroken" when Asians became the new tenants after his grandmother's death (Tyler, 2004). He also showed Tyler his ex-girlfriend's parent's house, explaining that it: "was very nice but a bit over the top". Tyler and Mike drove on out of Coalville into the countryside surrounding the town. Mike said "no lights - this is the countryside proper and that's why it's Tory [i.e. Conservative] country round here", as opposed to the politically Labour orientated and brightly lit and thus more densely populated town of Coalville. They came upon an extremely bumpy road. Mike explained that the road was mangled by subsidence from the water flooded coalmines that lay beneath it.

As they headed towards the village where Tyler was living, Mike pointed out "the Scotch Estate" - a large council estate built to house miners, and their families, that came to Coalville for work from the coalfields of Durham and 
Scotland in the 1960s. He told Tyler how the current generation of children 'born and brought up' on the estate had Scottish accents inherited from their parents and grandparents.

At one poignant moment of their journey, Mike stopped the car to look down on the lights of Coalville which lay in front of them. He said that's what makes me "well up". That is to say this view of Coalville is emotional for Mike and brings tears to his eyes. And yet at the same time Mike was the first to criticise people that do not leave the area to try something new and different somewhere else.

\section{Analytical reflections: seeing through the lens of intersection(ality), identity and belonging}

The writing and juxtaposition of these vignettes helped clarify for us both the "power of intersection" in our own research experiences as well as in the literature more widely. The people we both came to meet and know - via our respective immersion within particular locales - experienced and narrated a sense of connection and belonging which was achieved through a "claim on those things that belong to place" (Edwards \& Strathern, 2000, p. 151). The research participants we worked with constructed chains and links of 
association between animate and inanimate elements in diverse and locally specific ways. These practices and discourses enlarged their diverse senses of belonging to each other and to their place whether that be to the village, the town, the garden, the local characters and histories, the pub, the nation and so forth.

For instance, for some of the older people Degnen met, the Castle mediates linkages between memories from their youth that have become entangled with the physical realities of labour both inside and outside the Castle; the pleasures of enjoying the Castle's ample grounds; the comportment of characters such as the Captain and so on. These connections carry positive overtones and travel through time within oral histories, individual and shared memories, as well as personal objects such as Edna's postcard. This is indeed a complex web of attachments, subjects, objects, places, histories and memories that are mobilised to make claims of belonging and identity.

And yet, the intrusion of the recent regeneration project that pruned back the gardens served not only to disrupt the flow of these attachments but also to end the once easy and free access that Degnen's research participants had to the gardens. Thus the regeneration of the Castle signals an interruption to the 
"reciprocal physicalities" (Rapport, 2002, p. 304) once shared amongst the people Degnen came to know via working, dancing, walking and socialising together at the Castle. In short, the Castle's regeneration is an "emblem of nonbelonging" (Rapport, 2002, p. 304) that forms a boundary and feeling of separateness between Degnen's research participants and the visitors who do not belong to the Castle and its past in the intimate way that they do, or did.

Similarly, a focus on the intersection of social life and sociality enables us to see what shapes Mike's narrative of belonging to Coalville. While Mike is too young to have worked in the coal-mining industry, that history and its legacies mediates his description of place and his sense of connection to the town's pubs, the roads mangled by subsidence from abandoned coalmines, and local housing such as the estate built to accommodate migratory mining families. In this way, and like the older generation of people whom Degnen worked with, Mike's identity becomes "linked up" (Edwards \& Strathern, 2000, p. 152) with the history of place - its houses, its people - including the wider national and global histories of industrialism and post-industrialism that shaped the collapse of the coalmining industry in both Dodworth and Coalville. 
In thinking through her evening with Mike, what also strikes Tyler are the ordinary, everyday distinctions that Mike drew between the streets, the houses, and the types of people that lived there, and the differences that he evokes between the people who live in the countryside and the town. Like the distinctions separating the landed gentry who owned Wentworth Castle and those people from the local villages that maintained it, these everyday discourses of difference abound and are employed to mark connection and disconnection.

But can an anthropological focus on intersection of various domains of sociality in the making of attachments and disconnections become rendered more complex if we consider this material in light of non-additive identities of intersectionality? What if these personal and shared discourses of belonging, inclusion and exclusion are also explored in terms of how class, ethnic, racial, national and gendered, sexual and aged identities and inequalities are lived and experienced (Choo \& Ferree, 2010)? Local discourses that intersect to form belonging, attachment and disconnection that anthropologists demonstrate take on an added layer of meaning when seen via the sociological lens of intersectionality - but reciprocally, this is a nexus of meaning which intersectionality could not achieve without attention to the cultural logics 
underpinning them in the first place. Important here too, as both these approaches to identity and belonging illuminate, is the way in which these identities take meaning within specific local and located contexts that by definition are shaped by wider global and historical processes (Edwards, Evans, \& Smith, 2012; Brah, 2000).

The layered multi-directionality of this process is nicely illustrated by Margaret's recollection that the Captain who owned the Castle dressed so badly he "looked just like a tramp". On the one hand, the Captain is separated and distinct from Margaret in classed terms of financial wealth and social capital (Skeggs, 1997). But yet, on the other hand, the Captain also figures within Margaret's feelings of belonging and claims of attachment to the locality. We suggest that this is in part due to the Captain's divergence from what Margaret might expect from someone across such marked class lines, but also, importantly that it reveals Margaret's ability to claim him via her "knowing" him (Degnen, 2013) as well as to stake a claim to a shared, more egalitarian belonging that places them both in relation to that particular place and location, despite other profound differences. In this sense, then, classed identities and distinctions defined by access to differing kinds of capital take meaning within relations of connection 
and disconnection to place, memories, work and people that constitute local forms of belonging.

Advancing within the framework of a non-additive approach to identity formation, Degnen observes in her description of Wentworth Castle, these classed discourses of difference and otherness are always already gendered and aged. These are aspects of identity (like the often unmarked racial category of white ethnicity, a point we shall return to below) that can all too easily be rendered invisible in the analysis of mining communities associated with cultures of youthful and middle-aged white masculinities. But Degnen's research participants' speak from subject positions that later life affords. Their relationships with the Castle highlight the often overlooked significance of working class women's paid work to home, family, local and national economies. Via the numerous women who scrubbed, washed, dusted, polished, and cooked, the Castle speaks to hidden histories of women's work. This is particularly important in what is often stereotyped as a region and time where employment is interpreted as male industrial work, and women's work was said to be only in their homes. 
In Coalville, gendered, sexual, classed and aged distinctions and identities merged. They were most stark in Mike's request to Tyler in the first pub they visited not to "sit there because that's where all the slappers ${ }^{3}$ sit", the predominantly white male spectators of the football match, and in the more respectable pouring of Tyler's drink in 'a lady's glass', as well as the teasing speculation from her housemates about the nature of her relationship with Mike. For Mike, Tyler's comportment indicated a certain classed, gendered and sexualised respectability that in his mind separated her from some local women that he routinely met on nights out in Coalville. And yet these relations also revealed how Tyler's going out in Coalville with a 'bloke' rendered her activities familiar to and thus connected her with her housemates via assumptions of shared heteronormative sociality associated with being young, single and female.

In both Degnen's and Tyler's narratives, the whitened ethnic and racial constitution of their research participants' identities is always already present but is rendered explicit by the sporadic reference to and appearance of people identified as racially and ethnically 'other' to the racially unmarked white majority. That is to say, it becomes clear that references to "Asians" and

\footnotetext{
3 "Slappers" is slang for sexually promiscuous women.
} 
"African Americans" point to how narratives of empire, race and nation are salient and inscribed in each account. The effect of this is to highlight the ways in which our accounts of class, aged, gender and sexual identities, differences and inequalities located in relations of connection and disconnection are concomitantly about the privileges associated with being white. As such, combining anthropological and sociological approaches to intersection and intersectionality allows us to see how local relations of belonging, inclusion and exclusion are framed not only by the wider global and historical processes of de-industrialisation but also discourses of nationhood and racialisation formed in part by the legacies of colonialism. Indeed, Mike's knowledge that his uncles were 'heartbroken' that Asians now live in his grandmother's house illuminates how this form of localism can easily spill over into racism (Tyler, 2012).

In Dodworth, the global politics of hegemonic power that underpin the histories of the British empire are evident not only in the objectification of African Americans as 'people like them', but is also literally inscribed in the landscape via the Union Jack garden. In Coalville, in this example at least, the white male spectators' identification with the English football team in their game against Moldova unequivocally unites and connects them. Moreover, the public rituals to mark the death of Princess Diana reinforce and expand in an intimate way 
this already collective sense of national belonging to England, highlighted by the inscription of DIANA on the English flag of St. George. But yet, Mike's description of 'the Scotch Estate' and the people who live there illuminates how these feelings and affective ties of belonging to England sit alongside a sense of difference, but not indifference, to local people that come from Scotland.

\section{Conclusions}

Our argument is that drawing together the sociology of intersectionality with the anthropology of intersection deepens and enriches our analysis of our ethnographic material in ways that we would not otherwise have seen if we were interpreting it through either 'just' an anthropological or 'just' a sociological lens. We suggest that an anthropological approach to intersection when applied to the study of identity and belonging in Britain draws attention to the formation of a "common discourse, by which a certain structure is given to local life" (Rapport, 2002, p. 318) that reveals and examines how the various components of social realities are held together and/or kept apart.

While this common discourse is "a convenient home for the expression of a great and changing diversity of meanings", it nonetheless points us towards a 
logic and form that illuminates a reckoning and practice that is at the "core" of British social life (Green, 2002, p. 198). This logic is manifest in the daily formation and everyday experience of connections as well as disconnections and ruptures between memories, places, people, histories, objects and so on that constitute the fabric of British social life. By linking these observations on intersection from the anthropological study of Britain with the feminist sociological concept of intersectionality we are invited to "show how gender, race, and class can be seen as working together to draw boundaries and reproduce ...inequalities" (Choo \& Ferree, 2010, p. 137) in and through this common discourse. One consequence of this is to deepen both sociological and anthropological analysis of belonging and identity.

In this way, our analysis highlights how each perspective on identity, difference and belonging has its blind-spots which are strengths in the other. On the one hand, an intersectional approach to sociality when practiced in Britain has an expansive quality illuminating the seemingly endless connections and disconnections that people make in their claims to belong to places, to pasts and to each other. But yet this anthropological approach to the analysis of sociality can risk having a depoliticising affect. Indeed, it seems to us that more often than not the anthropology of Britain (including our own work) has tended 
to overlook the "significance of unmarked categories not only in the data but in the analysis to draw out power processes" (Choo \& Ferree, 2010, p. 137). On the other hand, however, the sociology of intersectionality is a highly politicised approach to the study of identity - motivated and driven by the need to confront inequalities and exploitation. But yet, such an approach when viewed through an anthropological perspective limits understanding of the lived contexts in which inequalities and differentiation take hold and carry meaning.

Our contention is that the bringing together of these complementary but distinct approaches demands a certain level of reflexivity on the part of the researcher in relation to what it means to work, live and think amongst the disciplines. For example, in her previous work, Tyler renders the classed constitution of white ethnic and racial identities visible (see for example Tyler, 2012) but she undertheorises the aged, gendered and sexualised constitution of these identities; similarly, while Degnen has brought age and gender into focus in her ethnographic writing (Degnen, 2012), class, sexuality and ethnicity drop away. And yet, such entailments can also become over-determined. So, on the one hand, whilst we want to keep an eye of the various forces and classifications that subtly (and not so subtly) shape lives, on the other hand, not all registers of inequality are always in play, either. Additionally, some are deliberately 
downplayed at times because others are more salient - and attending to how the people we work with call some elements into focus whilst screening others out is precisely one of the lessons to be learned from the anthropology of intersection we discuss above (Edwards, 1998).

Perhaps most significantly, as our ethnographic analysis shows, we have learnt that these sociological and anthropological approaches to identity are not stable nor fixed. Instead they are approaches that are always already intersecting in the details of our ethnographic data and interpretative practices. Thus, we conclude that our analysis here demonstrates how intersection and intersectionality are something more than simply two analytical perspectives working together. That is to say, like the intersectional constitution of identities themselves, these sociological and anthropological analytical frames are not mutually additive elements that can be conjoined, layered and taken-apart. Rather, these approaches become entangled and 'baked' (returning to our cooking metaphor earlier) in our ethnographic material and interpretative practices to become something more than the sum of their sociological or anthropological parts. It is an appreciation of this intersected relation that we conclude can constitute the practice of an anthropology of Britain in conversation with sociology. 


\section{Works cited}

Anthias, F. (2013). Moving beyond the Janus face of integration and diversity discourses: towards an intersectional framing. The Sociological Review, 61(2), 323-343.

Brah, A. (2000). Difference, diversity, differentiation. In L. Back, \& J. Solomos (Eds.), Theories of race and racism, a Reader (pp. 431-446). London: Routledge.

Carbado, D. (2013). Colorblind intersectionality. Signs, 38(4), 811-845.

Choo, H. Y. \& Ferree, M. M. (2010). Practicing intersectionality in sociological research: a critical analysis of inclusions, interactions, and institutions in the study of inequalities'. Sociological Theory, 28(2), 129-149.

Cohen, A. P. (Ed.) (1982). Belonging, identity and social organisation in British rural cultures. Manchester: Manchester University Press. 
Cohen, A. P. (1987)., Whalsay: Symbol, segment and boundary in a Shetland Island community., Manchester: Manchester University Press.

Comaroff, J. \& Comaroff, J. (2012). Foreword: Thinking anthropologically, about British social anthropology. In R. Fardon, O. Harris, T. H. J. Marchand, C. Shore, V. Strang, R. A. Wilson, \& M. Nuttall (Eds.), Sage handbook of Social Anthropology (pp. xxviii-xli). London: Sage.

Crenshaw, K. (1991). Mapping the margins: intersectionality, identity politics, and violence against women of colour, Stanford Law Review, 43(6), 1241-1299.

Crenshaw, K. (1989). Demarginalizing the intersection of race and sex: a black feminist critique of antidiscrimination doctrine, feminist theory, and antiracist politics. University of Chicago Legal Forum, 14, 538-554.

Davis, K. (2008), Intersectionality as buzzword: a sociology of science perspective on what makes a feminist theory successful. Feminist Theory, 9(1), 67-85. 
Degnen, C. (2005). Relationality, place, and absence: a three-dimensional perspective on social memory. The Sociological Review, 53(4), 729-744.

Degnen, C. (2013). "Knowing", absence and presence: the spatial and temporal depth of relations. Environment and Planning D: Society and Space, 31(3), 554570.

Degnen, C. (2012). Ageing selves and everyday life in the north of England: Years in the making. Manchester: Manchester University Press.

Donaldson, A., Ward, N., \& Bradley, S. (2010). Mess among disciplines: interdisciplinarity in environmental research. Environment and Planning A, 42(7), 1521-1536.

Edwards, J. (1998). The need for a "bit of history": place and past in English identity. In A. Lovell (Ed.), Locality and belonging (pp. 147-167). London: Routledge.

Edwards, J. (2000). Born and bred: Idioms of kinship and new reproductive technologies in England. Oxford: Oxford University Press. 
Edwards, J., \& Strathern, M. (2000). Including our own. In J. Carsten (Ed.), Cultures of relatedness: New approaches to the study of kinship (pp. 150-166). Cambridge: Cambridge University Press.

Edwards, J., Evans, G., \& Smith K. (2012). Introduction: the middle classification of Britain. Focaal, Journal of Global and Historical Anthropology, 62, 316.

Frankenberg, R. (1957). Village on the border. Cohen \& West: London.

Green, S. (2002). Culture in a network: Dykes, webs and women in London and Manchester. In N. Rapport (Ed.), British subjects: An anthropology of Britain (pp. 164-181). Oxford: Berg.

McCall, L. ( 2005). The complexity of intersectionality. Signs, 30 (3), 17711800.

McClintock, A. (1995). Imperial leather: Race, gender and sexuality in the colonial contest. London: Routledge. 
Rapport, N. (1993). Diverse worldviews in an English village. Edinburgh: Edinburgh University Press.

Rapport, N. (2002). The body of the village community: Between Reverend Parkington in Wanet and Mr Beebe in A Room with A View. In N. Rapport (Ed.), British subjects: An anthropology of Britain( pp. 282-299). Oxford: Berg.

Skeggs, B. (1997). Formations of class and gender. London: Sage.

Strathern, M. (1994). Parts and wholes: Refiguring relationships. In R.

Borowsky (Ed.), Assessing cultural anthropology (pp. 204-216). New York: McGraw Hill.

Strathern, M. (1981). Kinship at the core: An anthropology of Elmdon, a village in north-west Essex in the Nineteen-Sixties. Cambridge: Cambridge University Press.

Tyler, K. (2005). The genealogical imagination: The inheritance of interracial identities. The Sociological Review, 53 (3), 475-494. 
Tyler, K. (2004). Racism, tradition and reflexivity in a former mining town. Ethnic and Racial Studies, 27 (2), 290-309.

Tyler, K. (2012). Whiteness, class and the legacies of empire: On home ground. Basingstoke: Palgrave Macmillan.

Werbner, P. (2002). Imagined diasporas among Manchester Muslims. Santa Fe: James Currey \& School of American Research.

Walby, S., Armstrong, J., \& Strid, S. (2012). Intersectionality: Multiple inequalities in social theory. Sociology, 26(2), 224-240.

Yuval-Davis, N. (2007). Intersectionality, citizenship and contemporary politics of belonging. Critical Review of International Social and Political Philosophy, 10(4), 561-574. 